\title{
The Different Methods of Using Imam Al Sadiq's Traditions in Shahrestani's Interpretation
}

\author{
Safaa Kareem Al-Asadi \\ To College of Islamic Sciences, Karbala University, Iraq \\ karrm_asad@uokerbala.edu.iq
}

\begin{abstract}
Imam Al Sadiq as the founder of Jafarri School has left a great deal of hadiths which have influenced on shi'ite sources and also on sunni's interpretations books. One of the great sunni interpretations is Shahrestani who had used most of Imam Al Sadiq's hadiths in his interpretation and Imam influenced on his thoughts, so this subject makes the studying and analyzing of Imam Al Sadiq's hadiths which are used in Shahrestani's interpretation more important. This study has analyzed "Mafatih Al-Asrar and Masabih AlAbrar of Shahrestani" by descriptive-documentary method and also extracting Imam Al Sadiq's traditions and their kinds concluded that Shahrestani had used Imam Al Sadiq's hadiths in different methods. Sometimes he used Imam Al Sadiq's hadiths in preferential method, it means that Imam's saying is preferred to other view, and sometimes his using is in confirmatory method which confirms either Imam's speech with other traditions or confirms his own speech and others with Imam's tradition, and sometimes his using is a fundamental and as a key for conception and interpreting of Quran. So in this way, the present study introduces most important of these methods.
\end{abstract}

Keyword: Imam Al Sadiq; Shahrestani; Interpretative; Traditions

\section{Introduction}

Imam Al Sadiq as a one of guides of ummah has left most important interpretations and explanations in memento after the prophet (PBUH), recognizing of these traditions can be suitable method for reaching real interpretation of Quran. All experts confess that the knowledge of Quran is specified to Household of prophet (PBUH) as Shahrestani utters:

"The companions agree that knowledge of Quran is specified to household of prophet, because everyone asked Imam Ali, do you get something except knowledge of Quran. He said: "by the one whom splited the grain and created the generations, nothing except what is in my sword's sheeth", then he continues his speech in this way: "that the Quran is specified means that it is descended to household of prophet.

The majority of traditions are reached to us are specified to Imam Al Sadiq.

This venerable Imam has elevated the status of the pure Mohammadian Islam in different methods and according to individuals' comprehensive capacity, capability and talents of persons. And also he tried a 
lot to sustain Islam and introduce the truth of Quran to others. The results of these efforts have appeared in traditions which are reached by shite and also in sunni books as Shahrestani's interpretation that using Imam Al Sadiq's tradition are more obvious than sunni sources. So writer of this study wants to analyze and classify different kinds of Imam's traditions in order to clarify the high position of Imam and recognize his different methods in explaining of Quran.

\section{Fundamental Using}

In different cases, Shahrestani presented some traditions of Imam and inferred some principles that can be useful for understanding and explaining of Quran.

\subsection{The Household of Prophet}

There are some traditions of Imam Al-Sadiq in the introduction of Shahrestani's interpretation book. In these traditions, Imam has talked with his companions. As an example: it is narrated from Jafar ibn Mohammad that a man asked him and told:

The number of people who are closed to us that Almighty God says "so ask the people of knowledge, if you don't know". It is said that "mentioning referred to Torah, and people of knowledge referred to Jewish scholars"; but Imam said "by the God, they want to invite us to their religion by this way but by the God, we are the people of knowledge whom Almighty God ordered other people to refer your subject to these people. Also Imam Ali said that we are the people of knowledge, so in this way Shahrestani has uttered that knowledge should be acquired from Imam Al-Sadiq and Household and all issues should be referred to them. So according to Shahrestani's view, one of the principles of understanding Quran are pure and infallible Households Specially Imam Al-Sadiq.

\subsection{Household as Authority of Quran Conception}

Shahrestani's view about condition Quran interpretation: exegetes become confused because they don't get real knowledge which is related to Household and then he utters the conversation between Imam Al-Sadiq ans Sodeir Al-Seirafi as follows:

Sodeir says " I would die for you, Shi'a have different ideas about you, some groups believe that you hear a voice, some groups say knowledge inspired to you, and some others say knowledge hold in your heart, and some say you see dream, and others claims that you judge according to your father's book; which view should I adopt? Imam said: don't follow these considerations, O Sodeir! We are sign of God and people in the earth. Lawful and forbiddance are based on God's book; Sodeir accepts Imam's speech and utters that Households are sign of God and people and their lawful and forbiddance are based on God's book, so exegetes should consider household as real authority of Quran interpretation.

\subsection{Quran interpretation without Assumption}

Shahrestani utters some conditions for explaining of Quran exegetes in introduction of chapter12, and then he says: it is too hard to follow these conditions, so most of exegetes follow their assumptions, and then he refers to Imam Al-Sadiq's aversion to this kind of interpretation as an evidence for his own claim. He says: observing these conditions is too difficult in the interpretation of homologous verses and in explanation of verses. Qadria and Ash'arites interpret verses of Quran based on their own religion, and Moshbeheh obligate apparently, while Imam Al-Sadiq has expressed his aversion to all of them. Here, Shahrestani utters important principles, that is, interpretating of Quran according to exegetes' assumption cause deviation in his thought. 


\section{Preferential Using}

Preferential using is related to some cases which Shahrestani prefers Imam Al-Sadiq's opinions to other opinions. He utters his speech about Households' hidden knowledge in this way: there is no general word unless it is specified and there is no specification unless it needs recognizing and recognizing is related to secrets and Households know these secrets. Preferring Imam Al-Sadiq's traditions in Shahrestani's interpretation are in different subjects and they are observed in different forms. We exemplify some of them as follows:

\subsection{Preference in Households' Virtues}

Shahrestani interpreting verse of 13 from surah Al-Baqare, "when it is said to them, believe as the people believe...", when he speaks about word of "people", he says: "this word is used in Quran in general and specific way. The general way is like this verse: O you people, serve your Lord... (21, Al-Baqare). The specific way is like this verse: "Then press from where the people press on..." (199 Al-Baqare). And maybe the specific application is related to specific person which is great leader as prophet (PBUH). He continues his speech by uttering Imam Al-Sadiq's tradition. Imam says: "we are people and our Shi'ites is similar to us and others are Nasnases". According to Imam's speech, Shahrestani denote only Household of prophet to this tradition. Uttering this tradition by Shahrestani and considering to the term of "people" show his respect to Household of prophet as a prominent Sunni scholar.

Noteworthy that he has mentioned this tradition on several occasions in his interpretation.

\subsection{Preferring with Explaining}

In some cases, Shahrestani prefer Imam Al-Sadiq's tradition to other speech and also explain Imam's speech. For instance, in the Alasrar section, he mentions beneath this verse "In The Name of God, the merciful, the compassionate". He is uttering the secret term of "Allah" and at the last secret of this verse he says: God reveals himself to his servants through his book, Quran, and it can be inferred from Jafar ibn Mohammad Al-Sadiq's speech, and then he starts to explain this tradition and says: "there are great names in his book which are related to his specific friends, for example lordship is manifested to one of his friends, mercifulness is manifested to another his friends, and compassionateness to the other one. As it is observed, Shahrestani explained this tradition after he mentioned it.

\section{Confirming Using}

This part is observed in two forms in Shahrestani's speech. Sometimes he confirms other's speech by Imam's speech and sometimes he confirms Imam's speech by others' speech.

\subsection{Confirming prophet's Speech by Imam's Tradition}

Shahrestani discussed about recitations in the fourth chapter of his introduction: companions and followers did not add anything to Quran, and also they did not interfere their views in interpretation of Quran, then Shahrestani uttered famous hadith of prophet which he says: if someone interpret Quran with his personal opinion, he makes mistake even his interpretation be true, and if he interprets Quran wrongly, his place is in the fire, after that Shahrestani uttered Imam Al-Sadiq's tradition, Imam says: wisdom of interpretation of Quran is distant from people . 


\subsubsection{Confirming Imam Ali's Speech by Imam's Traditions}

Shahrestani mentions beneath this verse "And those that believe, and do righteousness those are the inhabitants of paradise there they shall dwell forever." And then he speaks about inhabiting in fire in the Alasrar discussion and he utters that remaining in the fire has two conditions: committing sins and being surrounded by mistakes, and also remaining in the paradise has two conditions: believing God and his prophet and doing good deeds. Imam Ali says: "All goodness coming from loving us and household and all sins coming from hatting household". So according to this speech, committing sins coming from hatred, enmity, and confronting to households and the conception of "surrounded mistakes" is related to come out obedience and being enemy of household and it is narrated from Imam Al-Sadiq that: "recognizing our rights and then do whatever you like".

\subsubsection{Confirming Companions' Speech by Imam Al-Sadiq's Tradition}

Shahrestani has spoken about different opinions of companions about descending Quran in Ramadan mouth at his first chapter of introduction which is written about descending Quran. It is narrated from Ibn Abbas that Quran has been descended as a whole to the world's sky on the night of power. According to another tradition, Quran was descended to the much frequented house in the Ramadan mouth, and also it is narrated from Wasela ibn Alasqae that God descended Quran to prophet on $24^{\text {th }}$ Ramadan. After uttering these traditions, Shahrestani utters Imam Al-Sadiq's tradition which is confirmation of companions' tradition: "Everything has a spring and the spring of Quran is Ramadan mouth".

\subsubsection{Confirming His Own Speech by Imam's Tradition}

Shahrestani has spoken about opposition and unity in the tenth chapter of his interpretation. He says: But in Quran opposition and unity has based on separation of people, good / bad persons, believers / unbelievers, and the righteous/ sinful people. This is not a story unless it is about these two groups or confliction of these groups. Imam Al-Sadiq says: one half of Quran is about us and another half is about our enemies and actually everything which is about our enemies is related to us (it means that there is loving household or there is enmity of household). Shahrestani utters this hadith in order to confirm his speech which is about two sects of believer/ unbeliever and good/ bad people.

\subsection{Confirming Imam's Tradition by Others' Speech}

In some cases, Shahrestani confirms Imam's traditions by others' speech.

\subsubsection{Confirming Imam's Tradition by Prophet's Tradition}

Shahrestani mentions beneath this verse "but if they resolve on divorce, surely God is all hearing, all knowing" (Al-Baqare, 227). Firstly, Shahrestani has spoken about divorce and specially time after divorcing in the part of Alasrar, and then he has uttered Imam Al-Sadiq's tradition with this concept: a husband should not reject and annoy his wife, and then Shahrestani confirmed Imam's tradition by prophet's speech and conduct. The messenger of God abstained and forbid his wife for a mouth, until the following verse descended "O prophet, why forbid thou what God has made lawful to thee"(Al-tahrim, 1).

\subsubsection{Confirming Imam's Traditions by Imam Ali's Traditions}

Shahrestani mentions beneath this verse "God is not ashamed to strike a similitude even of a gnat, or aught about it as for the believers; they know it is the truth from their Lord but as for unbelievers, they say "what did God desire by this for a similitude? Thereby he leads many astray, and thereby he guides many and thereby he leads not astray save the ungodly (Al-Baqare, 26). 
Shahrestani has spoken about blind and astray people in the part of Alasrar and then he has uttered this tradition of Imam: believers are all things and unbelievers are nothing" because believers have God, so they have all thing". After that, he has spoken about unbeliever, then, he has uttered that Imam Ali was speaking with a man who was unable to answer general and specific subjects in Quran, and Imam Ali said: who is the protractor of believer and unbeliever? Man said: God, Imam said: you right and who is the master of believer and unbeliever? He said: God, Imam said: you wrong, because God is the master of believers not unbelievers.

\subsubsection{Confirming Imam's Traditions by Companions' Speech}

Shahrestani has spoken about tradition which is related to hidden layers in the $12^{\text {th }}$ chapter of introduction of his interpretation. This tradition is uttered in this way: Imam says: God's book has four parts: phrases, hints, subtleties, and truth.

And then, he has uttered the tradition of Ibn Mas'oud: Quran is descended in seven letters and every verse has an apparent and hidden concept and every letter has a beginning and extent. Shahrestani has uttered this tradition in order to confirm Imam's tradition explicitly.

\subsubsection{Confirming Imam's Tradition by His Own Speech}

Shahrestani mentions beneath this verse "The path of those whom thou has blessed, not of those against whom thou art wrathful, no of those who are astray" (Alfateha, 7); and then he has started Alasrar part in this way: those who have knowledge, faith, and know secrets of Quran have stated that: indeed, people are two groups: learned/ learner, and guide/seeker and other people are thirsty and hungry (they never be satisfied); and these are two groups and this is related to $7^{\text {th }}$ part ( $7^{\text {th }}$ part from Alfateha secrets). As it is observed, Shahrestani has uttered Imam's tradition and then he has explained and finally he has accepted Imam's speech. It is notable that Shahrestani at the end of $7^{\text {th }}$ chapter of his interpretation has explicitly that these secrets were narrated from household and intensity avoid interpreting by self-opinions and he has confessed that the antecedents of phrases like "Quran follower say" or "men of Alasrar" do not refer to himself but they actually refer to household of prophet who know all concepts of Quran. This tradition is narrated to the other Imam Al-Sadiq's sources in this way: "people are divided to two groups: learned and learner people and others are thirsty and the place of thirsty people is in the fire.

\section{Narrative Using}

When Shahrestani has uttered Imam's tradition with others' tradition, we have narrative using. Shahrestani has written about seeking refuge in the $5^{\text {th }}$ chapter of his introduction: when reader of Quran wants to start reading Quran, seeking refuge is emphasized as God says: "when you are reading Quran, so you take refuge with God from expelled Satan". Then Shahrestani has narrated this issue from the people Basra, Ibn Khadir, and the other companions and at last he has narrated tradition of Imam Al-Sadiq. Imam says: "I take refuge with the Lord who is all hearing and all-knowing from the evil of expelled Satan, and then, he has begun a new subject.

\section{Jurisprudential Using}

Although Shahrestani is follower of Shafie'e school, he occasionally prefers Imam's jurisprudential traditions to other views in the discussion of verses of Quran. Shahrestani says: according to correct news, 
household of prophet and Imam had read "in the name of God" loudly in prayers which should have been read loudly and it quietly in others and they had told that cases are related just to Fatimah's offspring.

Then, Shahrestani has uttered a hadith from Imam Al-Sadiq which Imam says: there is concealing in my religion and my ancestors' religion. It exists just in three cases: drinking wine, anointing feet, abandonment reading "in the name of God" loudly. Shahrestani has told his belief by uttering this tradition. He has believed that there is not concealing in reading "in the name of God" loudly, and it should be read loudly. Furthermore, he has used this tradition both in perforation method and in jurisprudential method.

\section{Conclusion}

By studying and analyzing Imam Al-Sadiq's traditions, it can be said: studying Mafatih Alasrar shows that there are different methods of using Imam Al-Sadiq's tradition which every method has special aspect. Preferential using: in this method, Imam's traditions are preferred to others' speech explicitly and implicitly. Confirmatory using: in this method, sometimes Shahrestani has uttered Imam's tradition to confirm speech of prophet, companions, and his own views and vice versa. Sometimes, he has confirmed Imam's tradition by other traditions or his speech. Sometimes, Shahrestani has uttered Imam's tradition which Imam is discussing with other people; and sometimes he uses Imam's tradition basically and in some cases, he narrates Imam's tradition beside other traditions without any explanation and confirmation. Concentrating on these traditions shows that they influence on Shahrestani's thought.

\section{References}

The Holy Qur'an.

Ayyashi, Mohammad ibn Masud (2000), Ayyashi Interpretation, Researched by: Hashim Rasouli Mahallaati, Almaktabah Al-Elmiah, Tehran.

Barqi, Ahmad ibn Mohammad ibn Khalid (1993), Almahasin, researched by Jalal Al-din Muhaddith, Dar Al-kotob, Qom.

Bahrani, Haashem. (1994), Al-Borhan fi Tafsir Al-quran Besat institution, Qom.

Bahaei, Mohamad ibn Hosean (1985), Meftah Al-Falah, Dar Al-Azvae publication, Beirut.

Feize Kashani, Mohammad Bin Shah Murtaza (1994), Al-Safi interpretation, Researched by: Hussain A'lami, Maktabah Publications, Tehran.

Feize Kashani, Mohammad Bin Shah Murtaza (1986), Al-Vafi, imama ali library Publications, Isfahan.

Horre Ameli, Mohammad. (1989), Vasaail Al-Shia, Aal Al-Bayt Institute, Qom.

Haskani, Obeid Allah ibn Abd-Allah (1990), Shavahed Al-tanzil li Qavaaed Al-Tfzil, researched by Mohammad Baqir al-Mahmudi, Al-tabeh li vezarat Al Saqeh and Al-Ershad Al-Eslami, Mjma Ihya AlSeqah Al- Eslamiah, Tehran.

Hakimi, Mohammad reza, Hakimy Mohammad (2000), Al-Hayat, Translated by Ahmad Aram, Office of Islamic Culture Publication, Tehran.

Homeiri, Abdullah ibn Ja'far (1992), Qorb Al-Asnad, Aal Al-Bayt Institution, Qom.

Helli, Hasan ibn Yusoof (1928), Nahj Al-Haqq and Kashf Al-Sedq, Dar Al-Ketab Lobnani Institution, Beirut. 
Ibn Hayyone, Noman bin Mohammad (2005), Daaem Al-Islam, Researhed by: Asif Faizi, Al-Bayt Institute, Qom.

Ibn Shahr Ashoob Mazandarani, Mohammad bin Ali (1999), Manaqib Aal Abi Talib, (A) (Labn Shhrashvb), Allama publication, Qom.

Jalali, Mohammad Reza (2004), Tuzih Al- Mellal, Eqbal publication, Tehran.

Kabir Madani, Alikhan (1998), Riyaz Al-Salekin fi Sharh Sahife Seyd Sajedin, Researhed by: Mohsen Hoseyni Amini, Islamic Publications Office, Qom.

Kufi, Forat ibn Ebrahim (1989), Forat al-kufi interpretation, Researhed by:Mohammad kazem ,Al-Tabe Institute, Tehran.

Koleini, Mohammad ibn Ya'qub (1987), Al-Kafi, Researched by: Ali Akbar Ghaffari - Mohammad Akhoundi, Daar Al-kotob Al-Islamiah, Tehran.

Majlesi, Mohammad Bagher (1983), Bihar al-Anwar fi Akhbar Al-Aemmah Al-At'har, Al-Vafah, Institution, Beirut.

(1984), Mer'athi Al-Oghoul fi Sharh Akhbar Aal Al- Rasoul, Researched by: Hashem Rasoul Mahallati, Dar Al-Kotob Al-Islamiah, Tehran.

Nouri, Hosean ibn Mohammd Taqi(1988), Mostadrak al-vasael and Mostanbet al-masael, Researhed by: AlBayt Institution, Al- Bayt Institution, Qom.

Qortabi, Mohamed Bin Ahmed (2007), Aljam Li ahkam Al- Quran, Dar Al-kotob Al-Arabi, Cairo.

Qomi Ali ibn Ibrahim (1984), Al- Qomi interpretation, Researched by: Tayyib Musus Jazayeri, Dar Alketab, Qom.

Qomi Mashhadi, Mohammad (1990), Kanz Al-Daqaeq and Bahr Al-Garaeb Interpretation, Researhed by:Hosean Dargahi, Ministry of Culture and Islamic Guidance, Tehran .

Shahrestani, Mohammad ibn Abd Al-Karim (2006), interpretation of Mafatih Al-Asrar and Masabih AlAbrar, researched by: Mohammad Ali Azarshab, center of Al-Bohouth and Al-Derasat Li Torath AlMakhlout, Tehran.

Saddoq, Mohammad bin Ali (1998), Amali, Ketabchi publication, Tehran. publication, Qom. (1984), Alkhesal, Researched by: Ali Akbar Ghaffari, Jaameah Modarresin

\section{Copyrights}

Copyright for this article is retained by the author(s), with first publication rights granted to the journal.

This is an open-access article distributed under the terms and conditions of the Creative Commons Attribution license (http://creativecommons.org/licenses/by/4.0/). 